\title{
Modulation of FAD-dependent monooxygenase activity from aromatic compounds-degrading Stenotrophomonas maltophilia strain KB2
}

\author{
Danuta Wojcieszyńska, Izabela Greń, Katarzyna Hupert-Kocurek and Urszula Guzik \\ Department of Biochemistry, University of Silesia in Katowice, Katowice, Poland
}

\begin{abstract}
The purpose of this study was purification and characterization of phenol monooxygenase from Stenotrophomonas maltophilia strain KB2, enzyme that catabolises phenol and its derivatives through the initial hydroxylation to catechols. The enzyme requires NADH and FAD as a cofactors for activity, catalyses hydroxylation of a wide range of monocyclic phenols, aromatic acids and dihydroxylated derivatives of benzene except for catechol. High activity of this monooxygenase was observed in cell extract of strain KB2 grown on phenol, 2-methylphenol, 3-metylphenol or 4-methylphenol. Ionic surfactants as well as cytochrome P450 inhibitors or 1,4-dioxane, acetone and n-butyl acetate inhibited the enzyme activity, while non-ionic surfactants, chloroethane, ethylbenzene, ethyl acetate, cyclohexane, and benzene enhanced it. These results indicate that the phenol monooxygenase from Stenotrophomonas maltophilia strain KB2 holds great potential for bioremediation.
\end{abstract}

Keywords: monooxygenase, Stenotrophomonas, phenols, inhibitors

Received: 16 May, 2011; revised: 11 July, 2011; accepted:

13 September, 2011; available on-line: 16 September, 2011

\section{INTRODUCTION}

Phenols are widely distributed environmental pollutants generating strong interest in their bioremediation. Numerous bacterial strains are capable of mineralizing aromatic compounds. The wide range of substrates that can be transformed by microorganisms makes them a powerful tool for the bioremediation of environmentally harmful substances. Degradation of phenolic derivatives by aerobic bacteria generally proceeds by series of oxygenations. The initial step in the bacterial degradation of these compounds is the conversion of aromatic substrates into dihydroxylated intermediates by the action of monooxygenases. The next step is catalysed by dioxygenases that cleave the carbon-carbon bond and open the ring. The product of the ring cleavage is finally transformed into intermediates that can enter the citrate cycle (Cafaro et al., 2004; Murray et al., 2007; Arora et al., 2010; Dresen et al., 2010; Fujieda et al., 2010; Plazmiňo et al., 2010).

Aromatic monooxygenases catalysing hydroxylation of aromatic compounds are divided into two groups: activated-ring and nonactivated-ring ones. The active sites of these enzymes usually contain FAD as a prosthetic group and a dinuclear iron centre in which two iron atoms are bridged by an oxygen atom (Fe-O-Fe) (Divari et al., 2003; Murray et al., 2007). They activate molecular oxygen though the formation of a reactive flavin (hydro) peroxide which attacks the substrate by an electrophilic mechanism (Moonen et al., 2002; Arora et al., 2010; Dresen et al., 2010; Plazmiňo et al., 2010).

In this paper, we describe the purification and characterization of a novel NADH-dependent, FAD-containing monooxygenase from Stenotrophomonas maltophilia strain KB2, an interesting model for studying catabolism of phenols because of its unique ability to transform a wide range of these compounds compared with other similar microorganisms (Guzik et al., 2009; Greń et al., 2010). This study includes determination of the substrate specificity and catalytic properties of the enzyme. As in the environment compounds that inhibit monooxygenase activity are frequently present together with the substrates, effect of various surfactants, organic solvents, and cytochrome P450 inhibitors on the enzyme activity is also presented.

\section{EXPERIMENTAL PROCEDURES}

Media and culture conditions. Stenotrophomonas maltophilia KB2 (NCBI accession number DQ230920) is a Gram-negative, aromatic compound-degrading bacterium isolated from activated sludge of a sewage treatment plant in Bytom-Miechowice in Poland as described previously (Guzik et al., 2009). Strain KB2 was induced in mineral salts medium (MSM) as described previously (Wojcieszyńska et al., 2011) in the presence of $10 \mathrm{mM}$ phenol. Cultures were incubated at $30^{\circ} \mathrm{C}$ and agitated at $130 \mathrm{rpm}$.

Preparation of enzyme. Cells were harvested in the late exponential growth phase and centrifuged at $5000 \times g$ for $15 \mathrm{~min}$ at $4^{\circ} \mathrm{C}$. The cells were washed with $50 \mathrm{mM}$ phosphate buffer, $\mathrm{pH} 7.0$, and resuspended in the same buffer. Cell suspension was sonicated 6 times for $15 \mathrm{~s}$ and centrifuged at $9500 \times \mathrm{g}$ for $20 \mathrm{~min}$ at $4^{\circ} \mathrm{C}$. The supernatant was ultracentrifuged at $150000 \times g$ for $1.5 \mathrm{~h}$ at $4^{\circ} \mathrm{C}$. The pellet, containing membrane-associated proteins, was resuspended in $40 \mathrm{mM}$ phosphate buffer and used for enzyme assays or for further purification. $\mathrm{Nu}$ -

e-mail: urszula.guzik@us.edu.pl

Abbreviations: 2-AP, 2-aminophenol; 3-AP, 3-aminophenol; 4-AP, 4-aminophenol; 2-CP, 2-chlorophenol; 3-CP, 3-chlorophenol; 4- $\mathrm{CP}$ 4-chlorophenol; 2-NP, 2-nitrophenol; 3-NP, 3-nitrophenol; 4-NP 4-nitrophenol; 2-MP, 2-methylphenol; 3-MP, 3-methylphenol; 4-MP, 4-methylphenol 
cleic acids were removed by centrifugation at $9500 \times g$ for $10 \mathrm{~min}$ after addition of $0.05 \mathrm{~g} / 100 \mathrm{ml}$ protamine sulphate. Obtained supernatant was fractionated with ammonium sulphate. Solid $\left(\mathrm{NH}_{4}\right)_{2} \mathrm{SO}_{4}$ was added to the extract to $20 \%$ saturation with constant stirring. After 30 min the precipitate was removed by centrifugation at $9500 \times g$ for $10 \mathrm{~min}$. The supernatant was loaded onto Desalt Spin Columns equilibrated previously with 40 $\mathrm{mM}$ phosphate buffer. The elution was obtained with the same buffer. The eluate was loaded onto a column Sephadex G-100 (1.6 $\mathrm{cm} \times 82 \mathrm{~cm})$ equilibrated with 40 $\mathrm{mM}$ phosphate buffer, $\mathrm{pH}$ 7.2. Elution was carried out with the same buffer at a flow rate of $1 \mathrm{ml} / \mathrm{min}$ and 2.5 $\mathrm{ml}$ fractions were collected.

Molecular mass determination. The value of the monooxygenase was determined by size exclusion chromatography on Sephadex G-100 in $50 \mathrm{mM}$ phosphate buffer, $\mathrm{pH} 7.0$, at $4^{\circ} \mathrm{C}$. Elution volumes were determined by $\mathrm{OD}_{280}$ measurements and, in the case of the monooxygenase, by enzyme activity. The molecular mass markers used as standards were as follows: ferritin (440 $\mathrm{kDa})$, catalase $(232 \mathrm{kDa})$, lactate dehydrogenase (140 $\mathrm{kDa})$, bovine serum albumin $(67 \mathrm{kDa})$, and trypsin $(24$ $\mathrm{kDa}$.

Enzyme assays. The monooxygenase activity was determined spectrophotometrically by measuring NADH oxidation $\left(\varepsilon_{340}=6220 \cdot \mathrm{M}^{-1} \mathrm{~cm}^{-1}\right)$ in $40 \mathrm{mM}$ phosphate buffer ( $\mathrm{pH} 7.0$ ) containing $44 \mu \mathrm{M}$ FAD, $4 \mathrm{mM}$ NADH and $10 \mathrm{mM}$ phenol derivative. One unit of enzyme activity was defined as the amount of $\mathrm{NADH}(\mu \mathrm{mol})$ the enzyme oxidized in the presence of substrate per minute at $30^{\circ} \mathrm{C}$ (Divari et al., 2003). Protein concentration of all examined fractions was determined by the Bradford method (Bradford, 1976).

The reductase activity of monooxygenase was assayed spectrophotometrically at $30^{\circ} \mathrm{C}$ by monitoring the reduction of cytochrome $c$ at $550 \mathrm{~nm}$ or dichlorophenolindophenol and nitroblue tetrazolium at $600 \mathrm{~nm}$ with a CECIL UV-Vis spectrophotometer (Cafaro et al., 2004). FAD reduction was measured in $40 \mathrm{mM}$ phosphate buffer ( $\mathrm{pH}$ 7.2) containing $40 \mu \mathrm{M}$ FAD, $1 \mathrm{mM}$ NADH, and various amounts of protein at $30^{\circ} \mathrm{C}$ under anaerobic conditions. Anaerobic conditions were achieved by introducing the reaction mixture into a gastight cuvette inside an anaerobic glove box filled with nitrogen (Xun, 1996).

$\mathrm{pH}$ and temperature optima of monooxygenase. The effect of $\mathrm{pH}$ on the enzyme activity was determined by measuring the activity at $30^{\circ} \mathrm{C}$ over the $\mathrm{pH}$ range of 4.0 to 14.0 using the following buffers: $0.05 \mathrm{M}$ phosphate/citrate ( $\mathrm{pH} 4.0$ to 4.5 ), 0.05 M Sörensen ( $\mathrm{pH}$ 5.0), 0.05 M phosphate ( $\mathrm{pH} 5.7$ to 8.0$), 0.05$ glycine ( $\mathrm{pH}$ 10.0 ), 0.05 Britton-Robinson ( $\mathrm{pH} 11.00$ to 12.00), and 0.05 ammonia/sodium hydroxide ( $\mathrm{pH}$ 13.00-14.00).

The optimum temperature was determined by assaying the enzyme activity at various temperatures $\left(5\right.$ to $40^{\circ} \mathrm{C}$ ) in $50 \mathrm{mM}$ phosphate buffer $(\mathrm{pH} 7.0)$. The enzyme and substrate solutions were pre-incubated, mixed, and the enzymatic reaction was followed at the same temperature.

Substrate specificity and kinetic studies. The catalytic parameters (Michaelis-Menten constant, $K_{\mathrm{m}}$, and maximum velocity, $V_{\max }$, ) were calculated by measuring initial linear rates of the enzymatic reaction after the
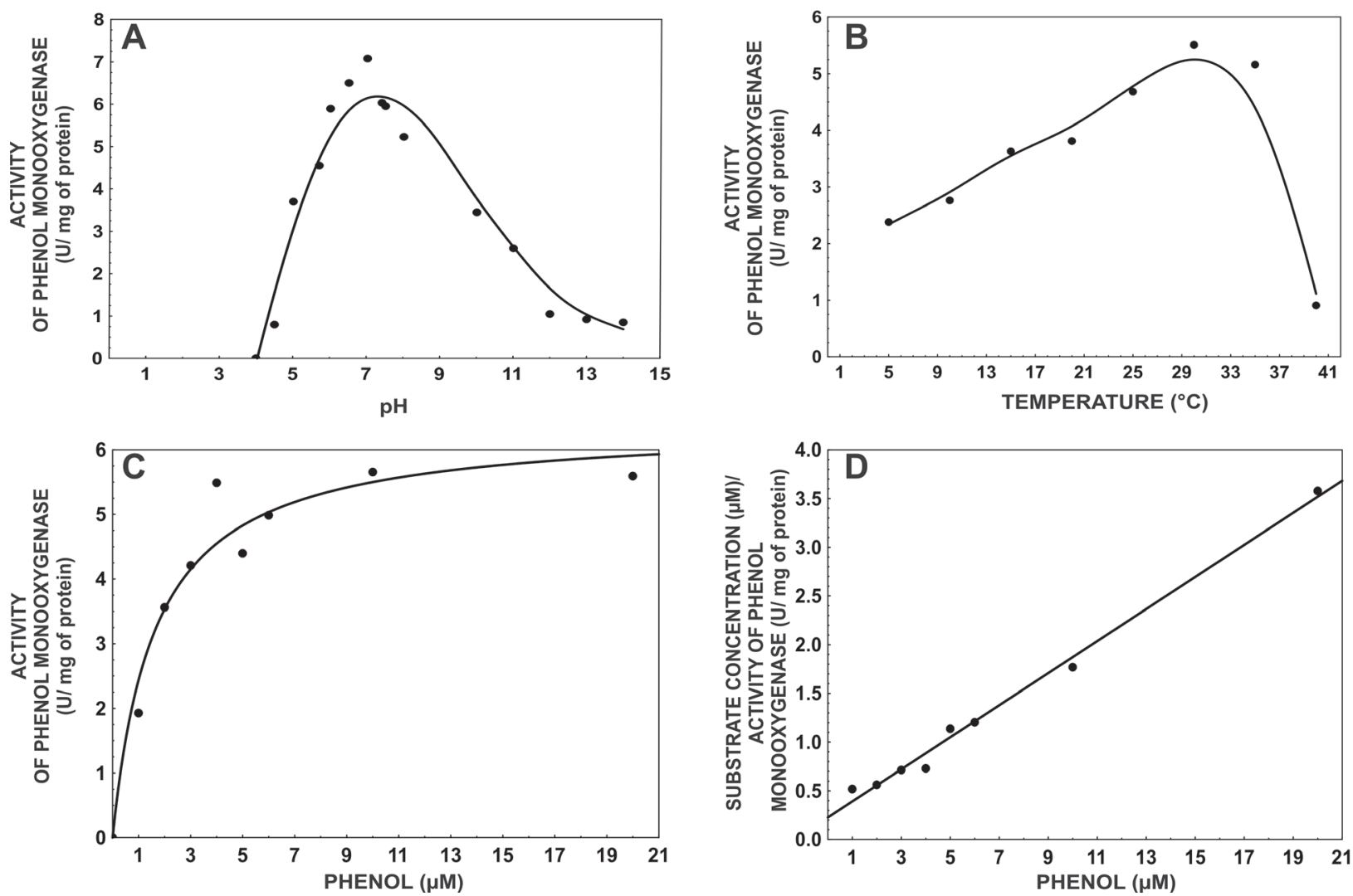

Figure 1. Effect of various factors on phenol monooxygenase activity in Stenotrophomonas maltophilia KB2 cell extract (A) $\mathrm{pH}$; (B) temperature; and (C, D) substrate concentration. Data points represent average of three independent experiments. 
Table 1. Purification of phenol monooxygenase

\begin{tabular}{|c|c|c|c|c|c|}
\hline Fraction & $\begin{array}{c}\text { Total activity } \\
(\mathrm{U})\end{array}$ & $\begin{array}{l}\text { Total protein } \\
\text { (mg) }\end{array}$ & $\begin{array}{l}\text { Specific activity } \\
\text { (U/mg protein) }\end{array}$ & $\begin{array}{l}\text { Purification } \\
\text { (fold) }\end{array}$ & $\begin{array}{c}\text { Yield } \\
(\%)\end{array}$ \\
\hline F1- cell extract & 19.05 & 4.35 & $4.38 \pm 1.09$ & 1.00 & 100 \\
\hline F2- centrifuge $(1718 \times g)$ fraction & 34.49 & 0.94 & $36.69 \pm 3.56$ & 8.4 & 181 \\
\hline F3- ultracentrifuge $(150000 \times g)$ fraction & 16.85 & 0.36 & $46.82 \pm 5.26$ & 11.0 & 88 \\
\hline F4- protamine sulphate treatment & 25.30 & 0.45 & $56.23 \pm 0.00$ & 13.0 & 133 \\
\hline F5- ammonium sulphate fraction & 29.09 & 0.19 & $153.13 \pm 25.41$ & 35.00 & 153 \\
\hline F6- desalt spin column fraction & 7.47 & 0.05 & $149.50 \pm 34.53$ & 34.13 & 39 \\
\hline F7'-peak 159 (Sephadex G-100 column) & 2.29 & 0.02 & $114.43 \pm 0.00$ & 26.13 & 12 \\
\hline
\end{tabular}

addition of different concentrations of phenol ranging from 0 to $20 \mu \mathrm{M}$ at $30^{\circ} \mathrm{C}$. Three independent measurements were carried out for each substrate concentration. $K_{\mathrm{m}}$ and $V_{\text {max }}$, were calculated from Hanes-Wolf equation.

The enzyme activity towards various substituted aromatic compounds was evaluated by incubating the enzyme with the respective aromatic substrate for $3 \mathrm{~min}$ and assaying the enzyme activity. The following substrates were assayed: aromatic acids: benzoic, protocatechuic, salicylic, 4-hydroxybenzoic, phthalic, cinnamic, 2-chlorophenylacetic, gallic, vanillic, and syringic acid; dihydroxy-substituted derivatives: hyroquinone, resorcinol and catechol; and a methyl derivative of catechol, guaiacol; derivatives of phenol: 2-chlorophenol (2-CP), 3-chlorophenol (3-CP), 4-chlorophenol (4-CP), 2-aminophenol (2-AP), 3-aminophenol (3-AP), 4-aminophenol (4-AP), 2-nitrophenol (2-NP), 3-nitrophenol (3-NP), 4-nitrophenol (4-NP), 2-methylphenol (2-MP), 3-methylphenol (3-MP), and 4-methylphenol (4-MP). All those substrates were used at $10 \mathrm{mM}$.

Effect of surfactants, organic solvents, and cytochrome P450 inhibitors on enzyme activity. The effect of various surfactants, organic solvents as well as cytochrome P450 inhibitors on the enzyme activity was evaluated by incubating the enzyme with the respective agent for $3 \mathrm{~min}$ and then assaying the residual enzyme activity with phenol as a substrate. The nonionic and ionic surfactants studied were: Triton X-100, Tween 20, oleic acid, stearic acid and sulphanilic acid. From among organic solvents, chloroethane, xylene, ethylbenzene, 1,4-dioxane, acetone, n-butyl acetate, ethyl acetate, cyclohexane and benzene were examined. As inhibitors of cytochrome P450, menadione, $\beta$-naphthoflavone as well as sodium azide were tested.

\section{RESULTS AND DISCUSSION}

Bacterial-derived enzymatic systems are of growing importance because of their potential use in bioremediation. Understanding the biochemical and structural properties of enzymes of degradation pathways is essential for their future potential applications. In this paper, we describe the purification and biochemical characterization of a novel NADH-dependent, FAD-containing phenol monooxygenase isolated from cultures of $S$. maltophilia KB2 induced by phenol.

In order to localise the monooxygenase activity in S. maltophilia KB2, the hydroxylation activity of the en-
Table 2. Substrate specificity of phenol monooxygenase

\begin{tabular}{|c|c|}
\hline Substrate & Activity, \% \\
\hline Phenol & 100.00 \\
\hline Benzoate & $74.36 \pm 2.10$ \\
\hline Salicylate & $136.72 \pm 5.60$ \\
\hline 4-Hydroxybenzoate & $128.38 \pm 7.52$ \\
\hline Phthalic acid & $87.02 \pm 6.10$ \\
\hline Cinnamic acid & $131.54 \pm 9.29$ \\
\hline Chlorophenoxyacetic acid & $137.95 \pm 5.88$ \\
\hline Gallate & $100.47 \pm 14.10$ \\
\hline Vanilic acid & $5.81 \pm 0.76$ \\
\hline Syryngic acid & $4.12 \pm 0.84$ \\
\hline Protocatechuate & $74.36 \pm 2.10$ \\
\hline Hydroquinone & $98.75 \pm 15.16$ \\
\hline Guaiacol & $62.59 \pm 14.64$ \\
\hline Resorcinol & $74.63 \pm 4.25$ \\
\hline Catechol & $0.00 \pm 0.00$ \\
\hline $2-C P$ & 34.00 \\
\hline $3-C P$ & 22.03 \\
\hline $4-C P$ & 41.24 \\
\hline 2-NP & 33.33 \\
\hline 3-NP & 18.79 \\
\hline 4-NP & 43.36 \\
\hline 2-MP & 39.83 \\
\hline 3-MP & 28.95 \\
\hline 4-MP & 71.61 \\
\hline 2-AP & 35.45 \\
\hline 3-AP & 37.57 \\
\hline 4-AP & 47.74 \\
\hline
\end{tabular}


Table 3. Effect of various surfactants on phenol monooxygenase activity

\begin{tabular}{|c|c|c|}
\hline Compound & Concentration (mM) & Relative activity (\%) \\
\hline None & & 100 \\
\hline \multirow[t]{4}{*}{ Triton X-100 } & 1 & $26.88 \pm 4.90$ \\
\hline & 2 & $37.29 \pm 0.00$ \\
\hline & 5 & $38.48 \pm 1.23$ \\
\hline & 10 & $406.64 \pm 0.00$ \\
\hline \multirow[t]{4}{*}{ Tween 20} & 1 & $104.69 \pm 16.81$ \\
\hline & 2 & $230.99 \pm 20.50$ \\
\hline & 5 & $163.28 \pm 18.76$ \\
\hline & 10 & $158.81 \pm 1.50$ \\
\hline \multirow[t]{4}{*}{ Oleic acid } & 1 & $0.00 \pm 4.61$ \\
\hline & 2 & $9.59 \pm 2.90$ \\
\hline & 5 & $0.00 \pm 0.00$ \\
\hline & 10 & $0.00 \pm 0.00$ \\
\hline \multirow[t]{4}{*}{ Stearic acid } & 1 & $71.45 \pm 19.54$ \\
\hline & 2 & $0.00 \pm 0.00$ \\
\hline & 5 & $0.00 \pm 0.00$ \\
\hline & 10 & $0.00 \pm 0.00$ \\
\hline \multirow[t]{4}{*}{ Sulphanilic acid } & 1 & $74.25 \pm 0.65$ \\
\hline & 2 & $66.19 \pm 1.99$ \\
\hline & 5 & $57.77 \pm 8.49$ \\
\hline & 10 & $7.88 \pm 3.59$ \\
\hline
\end{tabular}

zyme towards phenols was tested in two fractions of crude extracts of bacterial cells obtained after ultracentrifugation at $150000 \times g$ the supernatant containing soluble proteins and the pellet of membrane-associated proteins. Monooxygenase activity was detected only in the pellet fraction. In contrast to phenol hydroxylase from Acinetobacter radioresistens (Divari et al., 2003) and 2,4-dichlorophenol hydroxylase from Acinetobacter sp. (Beadle \& Smith, 1982), the monooxygenase from $S$. maltophilia KB2 seems to be an insoluble membrane protein.

The purification procedure described in the Experimental Procedures section enriched the monooxygenase approximately 34 -fold (Table 1$)$. The active fraction (114 $\mathrm{U} / \mathrm{mg}$ protein) obtained from Sephadex G-100 had a retention time of $152 \mathrm{~min}$. The molecular mass of the purified monooxygenase was estimated to be $34 \mathrm{kDa}$ by gel filtration. The low molecular mass of the enzyme suggested its monomeric structure, as reported previously for other hydroxylases (Batie et al., 1987; Xun 1996), but in contrast with many monooxygenases that form dimers and tetramers of high mass (up to $240 \mathrm{kDa}$ ) (Beadle \& Smith, 1982). The effect of temperature and $\mathrm{pH}$ on the phenol monooxygenase activity from KB2 strain was determined in cell extracts. The highest activity of the enzyme was observed at pH 7.2 (Fig. 1A). Moonen et al. (2002) described a hydroxylase from a Flavobacterium strain which was optimally active around $\mathrm{pH} 8.3$, and the most stable around $\mathrm{pH} 7.0$, as at $\mathrm{pH}$ above 7.5 the enzyme easily lost the FAD molecule.

The monooxygenase from KB2 strain was rather sensitive to thermal inactivation and can be categorised as a mesophilic protein. The optimal temperature for phenol oxidation was $30^{\circ} \mathrm{C}$. Above $35^{\circ} \mathrm{C}$ thermoinactivation of the enzyme was observed (Fig. 1B). Similar results were found for 4-monooxygenase from Burkholderia cepacia AC 1100 strain and hydroquinone hydroxylase from Candida parapsilosis CBS604. The optimal temperature for those enzymes was $35^{\circ} \mathrm{C}$ and $37^{\circ} \mathrm{C}$, respectively (Xun, 1996; Eppink et al., 2000).

The phenol oxidation by the monooxygenase from KB2 displays typical Michaelis-Menten kinetics. The $K_{\mathrm{m}}$ and $V_{\max }$ values were $1.62 \mu \mathrm{M}$ and $6.39 \mu \mathrm{M} / \mathrm{min}$, respectively (Fig. 1C, D). FAD was found to accelerate the reaction. It was also found that the presence of NADPH instead of NADH reduced significantly the monooxygenase activity, in contrast to the effect observed for chlorophenol 4-monooxygenase from Burkholderia cepacia AC1100 (Xun, 1996) and 2,4-dichlorophenol hydroxylase from Acinetobacter sp. (Beadle \& Smith 1982). A similar effect of NADH on xylene monooxygenase from Pseudomonas putida mt-2 was observed by Shaw and Harayama (1992). Studies on 4-hydroxybenzoate-3-hydroxylase have provided some insight into the mode of the coenzyme recognition (Eswaramoorthy et al., 2006). They postulate significant role of Arg-44, His-162 and Arg-269 in the interaction of the enzyme with NADPH. Arg-44 was involved in binding the adenosyl moiety and His162 and Arg-269 in binding the pyrophosphate moiety of NADPH while the acidic group of (Asp/Glu) was required for the recognition of the $2^{\prime}-\mathrm{OH}$ group of $\mathrm{NADH}$ (Moonen et al., 2002; Eswaramoorthy et al., 2006).

Flavoprotein monooxygenases that are active with phenolic compounds usually contain FAD as a prosthetic group. They activate molecular oxygen through the formation of a reactive flavin (hydro)peroxide which attacks the substrate by an electrophilic mechanism (Moonen et al., 2002; Kirchner et al., 2003; Eswaramoorthy et al., 2006; Dresen et al., 2010). Phenol monooxygenases generate reduced flavine at the expense of $\mathrm{NAD}(\mathrm{P}) \mathrm{H}$ and next transfer electrons to the iron ions (Shaw \& Harayama, 1992; Moonen et al., 2002). The FAD reduction by the studied enzyme was estimated to be $10 \mathrm{U} /$ $\mathrm{mg}$ of purified enzyme and indicated that FAD was the prosthetic group of this monooxygenase.

The monooxygenase from KB2 strain was also tested for its ability to reduce several artificial electron acceptor such as cytochrome $c$, nitrotetrazolium blue and 2,6-dichlorophenolindophenol, and was found to reduce only cytochrome $c$. The specific activity of the enzyme toward cytochrome $c$ was $7.55 \mathrm{U} / \mathrm{mg}$ of purified enzyme. The reaction catalysed by the phenol monooxygenase of KB2 strain is typical for a monooxygenase with an external electron donor such as 2,4-dichlorophenol monooxygenase or xylene monooxygenase (Beadle \& Smith, 1982; Shaw \& Harayama, 1992; Kirchner et al., 2003; Eswaramoorthy et al., 2006; Arora et al., 2010; Plazmiňo et al., 2010).

Many monooxygenases have narrow substrate specificities and regioselectivities, such as 3-hydroxyphenylacetate 6-hydroxylase from Flavobacterium. Besides 3-hydroxyphenylacetate, which was converted to 2,5-dihydroxyphenylacetate, the only alternative substrate was 3,4-dihydroxyphenylacetate (Moonen et al., 2002). Because monooxygenases are not only used in the biocata- 
Table 4. Effect of various organic solvents on phenol monooxygenase activity

\begin{tabular}{|c|c|c|}
\hline Compound & Concentration (mM) & Relative activity (\%) \\
\hline None & & 100 \\
\hline \multirow[t]{3}{*}{ Chloroethane } & 1 & $140.69 \pm 23.11$ \\
\hline & 2 & $218.79 \pm 0.70$ \\
\hline & 3 & $574.93 \pm 49.41$ \\
\hline \multirow[t]{3}{*}{ Xylene } & 1 & $131.98 \pm 7.29$ \\
\hline & 2 & $109.22 \pm 7.69$ \\
\hline & 3 & $106.55 \pm 5.70$ \\
\hline \multirow[t]{3}{*}{ Ethylbenzene } & 1 & $133.17 \pm 1.17$ \\
\hline & 2 & $138.01 \pm 1.04$ \\
\hline & 3 & $138.19 \pm 7.09$ \\
\hline \multirow[t]{3}{*}{ 1,4-Dioxane } & 1 & $138.11 \pm 9.27$ \\
\hline & 2 & $33.21 \pm 1.56$ \\
\hline & 3 & $5.15 \pm 0.99$ \\
\hline \multirow[t]{3}{*}{ Acetone } & 1 & $162.22 \pm 8.28$ \\
\hline & 2 & $81.56 \pm 1.60$ \\
\hline & 3 & $11.45 \pm 0.22$ \\
\hline \multirow[t]{3}{*}{ n-Butyl acetate } & 1 & $273.98 \pm 43.94$ \\
\hline & 2 & $283.15 \pm 6.30$ \\
\hline & 3 & $57.98 \pm 1.21$ \\
\hline \multirow[t]{2}{*}{ Ethyl acetate } & 1 & $422.63 \pm 31.23$ \\
\hline & 2 & $438.55 \pm 73.40$ \\
\hline \multirow[t]{4}{*}{ Cyclohexane } & 0.1 & $46.82 \pm 4.67$ \\
\hline & 0.2 & $132.51 \pm 15.38$ \\
\hline & 0.3 & $283.79 \pm 27.87$ \\
\hline & 0.4 & $331.29 \pm 1.25$ \\
\hline \multirow[t]{4}{*}{ Benzene } & 1 & $122.23 \pm 6.77$ \\
\hline & 2 & $141.77 \pm 18.16$ \\
\hline & 3 & $119.37 \pm 5.16$ \\
\hline & 4 & $154.61 \pm 27.61$ \\
\hline
\end{tabular}

lytic production of fine chemicals, pharmaceuticals and food ingredients but also are of interest for bioremediation, we sought for an enzyme which would metabolize a wide range of benzene derivatives, causing sometimes serious local contamination of the environment.

By measuring NADH oxidation in the presence of different aromatic compounds, the substrate specificity of the monooxygenase was tested. As shown in Table 2, the monooxygenase from $S$. maltophilia KB2 acted on a broad range of substrates, including methylated phenols, aromatic acids and their dihydroxylated derivatives. The enzyme showed preferences for hydroxylation of phenols with a substituent in the para-position such as 4-CP,
4-AP, 4-NP and 4-MP, which suggests that the para-position enabled orto-hydroxylation without a simultaneous removal of the substituent group. During the enzymatic conversion of dihydroxybenzenes we observed that catechol was a poor substrate of the enzyme (Table 2). As catechol is usually formed during phenol hydroxylation, the enzyme catalysing this reaction probably has a regulatory site responsible for inhibition of the enzyme in the presence of excess product. Results in Table 2 obtained for meta-substituted phenols indicate low affinity of enzyme active site for these substrates. We assumed that substituents in the meta-position might comprise a steric hindrance for the monooxygenase activity. The monooxygenase from KB2 strain metabolised all aromatic acids used in this study (Table 2), albeit vanilic and syryngic acids only poor. That was probably caused by the presence of the methoxy group in their structure (Ueng et al., 2000).

Most of the surfactants studied here affected the enzyme activity at all concentrations tested (Table 3). At lower concentrations of Triton X-100 there was a decrease in enzyme activity, whereas high concentration (10 $\mathrm{mM}$ ) of this surfactant enhanced the activity of the enzyme. Tween 20 did not affect the enzyme activity at its lowest concentration, whereas enhanced activity of the monooxygenase was observed at higher concentrations of this surfactant. Different results were obtained by Lattard et al. (2002) and Myasoedova et al. (2007), who did not observe an effect of nonionic detergents on monooxygenase activity. The increase in activity in the presence of surfactants may be attributed to increased substrate accessibility of the enzyme (Chellappan et al., 2010). In the presence of oleic, stearic and sulphanilic acids the monooxygenase activity decreased significantly. The inhibition of the enzyme at higher concentrations of ionic surfactants may be due to a combined effect of factors such as reduction in the hydrophobic interactions that play a crucial role in holding together the protein structure and direct interactions with the cell membrane.

Organic solvents affect enzyme activity via interactions with water, enzyme, substrate and product. It is well documented that hydrophobic solvents are usually better than hydrophilic ones, as the latter have a greater tendency to strip tightly bound water from the enzyme molecule (Shuster \& Fishman, 2009). In our studies pronounced stimulatory effects of chloroethane, ethylbenzene, ethyl acetate, cyclohexane and benzene on monooxygenase activity were observed (Table 4). The enzyme activity was slightly stimulated in the presence of ethylbenzene. Xylene had almost no effect, while 1,4-dioxane, acetone, and n-butyl acetate inhibited the enzyme (Table 4).

Multicomponent monooxygenases usually consist of three protein components: a hydroxylase, a cofactorless regulatory protein, and a FAD-containing reductase. However, there is also a large group of P450-containing monooxygenases where P450 acts as the terminal oxidase (Degtyarenko, 1995; Sazinsky \& Lippard, 2006). In our studies menadione, $\beta$-naphthoflavone and sodium azide were used as specific cytochrome P450 inhibitors. The concentrations of the inhibitors and percentage inhibition of hydroxylation are shown in Table 5 . The partial or complete inhibition of the enzyme activity observed with menadione and $\beta$-naphthoflavone clearly showed that the activity of monooxygenase of KB2 strain depends on cytochrome P450. We observed increased activity at the lowest concentration of menadion, but this effect is difficult to explain. Sodium azide slightly in- 
Table 5. Effect of cytochrome P450 inhibitors on phenol monooxygenase activity

\begin{tabular}{|c|c|c|}
\hline Compound & Concentration (mM) & Relative activity (\%) \\
\hline None & & 100 \\
\hline \multirow[t]{5}{*}{ Menadione } & 1 & $260.69 \pm 10.23$ \\
\hline & 2 & $19.35 \pm 4.21$ \\
\hline & 3 & $0.00 \pm 0.00$ \\
\hline & 4 & $0.00 \pm 0.00$ \\
\hline & 5 & $6.33 \pm 0.42$ \\
\hline \multirow[t]{3}{*}{$\beta$-Naphthoflavone } & 0.5 & $0.00 \pm 0.00$ \\
\hline & 1 & $0.00 \pm 0.00$ \\
\hline & 2 & $0.00 \pm 0.00$ \\
\hline \multirow[t]{4}{*}{ Sodium azide } & 1 & $105.82 \pm 3.24$ \\
\hline & 2 & $113.1 \pm 11.79$ \\
\hline & 5 & $118.1 \pm 8.28$ \\
\hline & 10 & $88.31 \pm 43.84$ \\
\hline
\end{tabular}

hibited the enzyme activity (Table 5) even though this heme ligand is generally regarded as a P450 inhibitor (Matsunaga et al., 1998). The mechanism of inhibitor action may involve their conversion into reactive intermediates which covalently bind to the active site of the enzyme blocking its interaction with the substrate (Beliaev et al., 2009). In our work we have shown that phenol monooxygenase from $S$. maltophilia KB2 is a typical flavoprotein monooxygenase that catalyses hydroxylation of a wide range of monocyclic phenols. Because of the high efficiency of substrate hydroxylation, the enzyme is an attractive candidate for bioremediation and biotechnological application. The results presented in this paper are a good starting point for further studies on the physicochemical properties of this enzyme and the structural features which determine its substrate specificity.

\section{Acknowledgement}

Katarzyna Lepsza is acknowledged for excellent technical assistance.

This work was supported by the Ministry of Science and Higher Education (grant N N305 212337).

\section{REFERENCES}

Arora PK, Srivastava A, Singh VP (2010) Application of monooxygenase in dehalogenation, desulphurization, denitrification and hydroxylation of aromatic compounds. J Bioremed Biodegrad 1-112 DOI: 10.4172/2155-6199.1000112.

Batie CJ, Haie E, Ballou DP (1987) Purification and characterisation of phtalate oxygenase and phtalate oxygenase reductase from Pseudomonas cepacia. I Biol Chem 4: 1510-1518.

Beadle CA, Smith AR (1982) The purification and properties of 2,4-dichlorofenol hydroxylase from strain Acinetobacter species. Eur J Biochem 123: 323-332.

Beliaev A, Ferreira H, Learmonth DA, Soares-da-Silva P (2009) Dopamine $\beta$-monooxygenase: mechanism, substrates and inhibitors. Curr Enaym Inhib 5: 27-43.

Bradford M (1976) A rapid and sensitive method for the quantitation of microgram quantities of protein utilizing the principle of proteindye binding. Anal Biochem 7: 248-258.
Cafaro V, Izzo V, Scognamiglio R, Notomista E, Capasso P, Casbarra A, Pucci P, Di Donato A (2004) Phenol hydroxylase and toluene/oxylene monooxygenase from Pseudomonas stutzeri OX1: interplay between two enzymes. Appl Environ Microbiol 70: 2211-2219.

Chellappan S, Jasmin C, Basheer SM, Kishore A, Elyas KK, Bhat SG, Chandrasekaran M (2010) Characterization of an extracellular alkaline serine protease from marine Engyodontium album BTMFS10. J Ind Microbiol Biotechnol DOI: 10.1007/s10295-010-0914-3.

Degtyarenko KN (1995) Structural domains of P450-containing monooxygenase systems. Protein Eng 8: 737-747.

Divari S, Valetti F. Caposito P, Pessione E, Cavaletto M, Griva E, Gribaudo G, Gilardi G, Giunta C (2003) The oxygenase component of phenol hydroxylase from Acinetobacter radioresistens S13. I Biochem 270: $2244-2253$.

Dresen C, Lin LY-C, D'Angelo I, Tocheva EI, Strynadka N, Eltis LD (2010) A flavin-dependent monooxygenase from Mycobacterium tuberculosis involved in cholesterol catabolism. J Biol Chem 284: 2264 2275.

Eppink MHM, Cammaart E, van Wassenaar D, Middelhoven WJ, van Berkel WJH (2000) Purification and properties of hydroquinone hydroxylase, FAD-dependent monooxygenase involved in the catabolism of 4-hydroxybenzoate in Candida parapsilosis CBS604. Eur J Biochem 267: 6832-6840.

Eswaramoorthy S, Bonanno JB, Burley SK, Swaminathan S (2006) Mechanism of action of a flavin-containing monooxygenase. Proc Natl Acad Sci 106: 9832-9837.

Fujieda N, Yakiyama A, Itoh S (2010) Five monomeric hemocyanin subunits from Portunus trituberculatus: purification, spectroscopic characterization, and quantitative evaluation of phenol monooxygenase activity. Biochim Biophys Act 1804: 2128-2135.

Greń I, Wojcieszyńska D, Guzik U, Perkosz M, Hupert-Kocurek K (2010) Enhanced biotransformation of mononitrophenols by Stenotrophomonas maltophilia KB2 in the presence of aromatic compounds of plant origin. World J Microbiol Biotechnol 26: 289-295.

Guzik U, Greń I. Wojcieszyńska D, Labużek S (2009) Isolation and characterization of a novel strain of Stenotrophomonas maltophilia possessing various dioxygenases for monocyclic hydrocarbon degradation. Braz I Microbiol 40: 285-291.

Kirchner U, Westphal AH, Müller R, van Berkel WJH (2003) Phenol hydroxylase from Bacillus thermoglucosidasidasius A7 a two-protein component monooxygenase with dual role for FAD. $J$ Biol Chem 278: $47543-47553$

Lattard V, Longin-Sauvageon Ch, Lachuer J, Delatour P, Benoit E (2002) Cloning, sequencing, and tissue-dependent expression of flavin-containing monooxygenase (FMO) 1 and FMO3 in the dog. Drug Metab Dispos 30: 119-128.

Matsunaga I, Yamada M, Kusunose E, Miki T, Ichihara K (1998) Further characterization of hydrogen peroxide-dependent fatty acid $\alpha$-hydroxylase from Sphingomonas paucimobilis. I Biochem 124: 105-110.

Moonen MJ, Fraaije MW, Rietjens IM, Laane C, Berkel WJ (2002) Flavoenzyme-catalyzed oxygenation and oxidations of phenolic compounds. Adv Synth Catal 344: 1023-1035.

Murray LJ, Garcia-Serres R, McCormick MS, Davydov R, Naik SG, Kim S-H, Hoffman BM, Huynh BH, Lippard SJ (2007) Dioxygen activation at non-heme diiron centers: oxidation of proximal residue in the $1100 \mathrm{~W}$ variant of toluene/o-xylene monooxygenase hydroxylase. Biochem 46: 14795-14809.

Myasoedova KN, Arutyunyan AM, Magretova NN (2007) Reconstitution of mooxygenase activity of membrane cytochromes P450 in vitro and detergents. Biochem Biophys Mol Bol 415: 262-267.

Plazmiňo DE, Winkler M, Glieder A, Fraaije MW (2010) Monooxygenase as biocatalysts: classification, mechanistic aspects and biotechnological applications. J Biotechnol 146: 9-24.

Sazinsky M, Lippard SJ (2006) Correlating structure with function in bacterial multicomponent monooxygenases and related diiron proteins. Acc Chem Res 39: 558-566.

Shaw J, Harayama S (1992) Purification and characterisation of the NADH: acceptor reductase component of xylene monooxygenase encoded by the TOL plasmid pWW0 of Psendomonas putida $\mathrm{mt}-2$. Eur I Biochem 209: 51-61.

Shuster V, Fishman A (2009) Isolation, cloning and characterization of a tyrosinase with improved activity in organic solvents from Bacillus megaterium. I Mol Microbiol Biotechnol 17: 188-200.

Ueng YF, Chen $\mathrm{ChCH}$, Chen $\mathrm{ChF}$ (2000) Inhibition of benzo(a)pyrene hydroxylation by lignans isolated from Justicia procumbens. J Food Drug Anal 8: 309-314.

Wojcieszyńska D, Guzik U, Greń I, Perkosz M, Hupert-Kocurek K (2011) Induction of aromatic ring - cleavage dioxygenases in Stenotrophomonas maltophilia strain KB2 in cometabolic systems. World J Microbiol Biotechnol 27: 805-811.

Xun L (1996) Purification and characterization of chlorophenol 4-monooxygenase from Burkholderia cepacia AC 1100. J Bacteriol 178: 2645-2649. 